\title{
Natural Science Teacher Perception on Subject Specific Pedagogy Integrated Earthquake Disaster Mitigation
}

\author{
Maya Izzatus Shofa ${ }^{1, *}$ Pujianto $^{2,}$ Ririn Elviana $^{1}$ \\ ${ }^{1}$ Master of Natural Science Education, Faculty of Mathematics and Natural Sciences, Universitas Negeri \\ Yogyakarta, Indonesia \\ ${ }^{2}$ Department of Physics Education, Faculty of Mathematics and Natural Sciences, Universitas Negeri \\ Yogyakarta, Indonesia \\ *Corresponding author. Email: mayaizzatusshofa@gmail.com
}

\begin{abstract}
This research is aimed to find out the perception of Natural Science teacher on subject specific pedagogy integratedof earthquake disaster mitigation. It is a descriptive research with 12 of Natural Science Candidates of Teacher and 14 Natural Science teachers. The research data is obtained by using validated questionnaire. The validity and reliability of questionnaire instrument are qualitatively analyzed by using SPSS application. The score of reliability is $0.785,0,799$ and 0,639 which means all three indicators of the questionnaire has high reliability. The data analysis technique is performed using quantitative percentage. The research result indicates that the perception of Natural Science teachers and teacher candidates on subject specific pedagogy is in good category which score is 80.35 . The aspect of teachers and teacher candidates' knowledge is 83.85 and is categorized as good. While the aspect of knowledge on Natural Science learning integrated by disaster mitigation of teachers and teacher candidates is 73.33 and is categorized as moderate criteria. SSP development in Natural Science learning should be performed and make it as a guidance and is used by teachers in implementing the learning. Much effort is required to prepare and support teachers in handling disaster in the classroom. Therefore, the development of SSP Natural Science which is integrated with earthquake mitigation can become a reference in performing disaster learning. It is potential to make Natural Science as one of disaster mitigation education medium.
\end{abstract}

Keywords: Teachers perception, Subject specific pedagogy, Earthquake disaster mitigation

\section{INTRODUCTION}

Indonesia is one of the most disaster-prone countries, because located among three tectonic plates [1]. The three plate namely the IndoAustralian, the Eurasian, and the Pacific plate which interact to each other. These interactions of tectonic plates, the region become active tectonic. The active tectonic related to some disaster such as earthquake [2]. In total, the eleven years (since 2009-2019) earthquake experience in Indonesia's territorial areas was 71,628 earthquake events with the average number of years, months and days respectively 6.512, 543 and 18 earthquake events (numbers were rounded) [3]. On May 27, 2006 a 6.4 magnitude of earthquake struck Yogyakarta Province. It had claimed more than 5.500 lives of victims and damages to buildings which were mostly found at southern part of Yogyakarta, such as Bantul [4]. One of the causes of the increasing number of victims was the absence of a proper disaster mitigation system.

Disaster mitigation is important to minimize the impact and damage of the earthquake disaster especially in school behavior. Disaster mitigation contains planing to be implementable into actions aimed at disasters. The planning process in mitigation is an effective form of disaster management. Disaster mitigation needs to be done together with stakeholders. Mitigation is part of the development process to achieve disaster resilience in communities [5]. The results of a survey conducted by Kompas in 
July 2011 in densely populated areas classified as disaster-prone, namely the cities of Banda Aceh, Padang, Bengkulu, Palu, Yogyakarta, and Karangasem, show that the majority of people are not ready for natural disasters. In fact, the awareness that they live in areas prone to natural disasters is still low. Nearly half of the 806 respondents in the survey stated that their area of residence is not prone to disasters. Even though it is clear that the area is classified as prone to disaster [6]. Disaster education is needed to overcome this.

The purpose of disaster education is to build a safety culture in the society, school community, government, and other stakeholders [7]. Awareness among the communities can also suported by schools. Moreover, schools can contribute to community's emergency plans [8]. Based on these descriptions, disaster education can be carried out through learning activities in schools. Natural science is one of the lessons which is relevant to be integrated with the disaster. It consists of many scopes, one of them is geology, which is included in Science lesson. Disaster mitigation can be done through learning on topic of earth layer material at grade VII of Semester 2. Therefore, through material, earthquake disaster mitigation is learned. This condition is expected to be able to build students' knowledge and attitudes about disaster.

Integration can be the form of learning designs in schools which are contained in the Subject Specific Pedagogy (SSP) form. SSP is the packaging of subject matter material into educational and comprehensive learning tools that include basic competency standards, materials, methods, strategies, media, and evaluation [9]. Natural science teachers are expected to be able to master content and delivering method (teaching) for students or which is known as PCK (Pedagogical Content Knowledge) approach. PCK present a basic to think that Natural Science involve how to tech, does not only merely understand the material. So, the natural Science teachers should have knowledge about the content of natural science material, learning strategy, curriculum, and assesment. Therefore, they are able to transform Natural Science. [10].

This research is a part of research which develops SSP because partially development stage is the level of Natural Science teachers and teacher candidates' knowledge towards Natural Science Learning SSP which is integrated with earthquake disaster mitigation. Therefore, this research is aimed to find out knowledge which is possessed by natural science teachers and teacher candidates on SSP Natural
Science, understanding on earthquake disaster, and how the integration of earthquake disaster mitigation content in Natural Science learning is.

\section{RESEARCH METHOD}

This research was quantitative descriptive research. This research was used to examine the science teachers perception toward their knowledge about Subject Specific Pedagogy integrated earthquake disaster mitigation. The population is Natural Science teachers and teacher candidates in DIY and the surrounding. Participants of this study were 12 Natural Science Teacher Candidates and 14 Natural Science Teachers. Samples taken using purposive sampling technique, for natural science teacher candidates and natural science teachers who perform teaching practice at school. The data was collected through an online questionnaire. Questionnaires were accessed by respondent on the free online survey form' URL.

The questionnaires consists of three sections to measure Natural Science teachers and Natural Science teacher candidates knowledge about SSP, earthquake disaster, and integrating of mitigation in science learning. All sections of questionnaire consisted of 26 items, were rated according on five point likert scale, namely $1=$ strongly disagree, $2=$ disagree, 3 = unsure, $4=$ agree, and $5=$ strongly agree. The instrument was validated in terms of content and construct by expert lecturer. The data of questionnaire was analyzed by using SPSS application version 22 to determine the instruments' validity and reliability. The result are provide in this following table 1.

The questionnaire analysis result indicates that five invalid items are item $1,26,39,43$, and 44 . It is confirmed as valid if the Sig score (2-tailed) $<0.05$, so the result on table 1 is valid item, while the invalid one is not utilized. Based on the valid item, reliability analysis is done and shows the following table 2 . Table 2 indicates that reliability score of each indicator is in high category that the alpha score is 0.600-0.799.

The questionnaire is then processed after collecting data using Microsoft Excel. The analysis data of this research use TCR' technique. This technique used to calculate achievement respondents level and relating criteria. The formula and classification of criteria achievement respondents level.

$\mathrm{TCR}=\frac{\text { Average Score }}{\text { Maximum Score }} \times 100 \%$ 
Table 1. Questionnaires validity test

\begin{tabular}{|c|c|c|c|c|c|}
\hline \multicolumn{2}{|c|}{$\begin{array}{l}\text { Subject } \\
\text { Specific } \\
\text { Pedagogy }\end{array}$} & \multicolumn{2}{|c|}{$\begin{array}{l}\text { Disaster } \\
\text { Mitigation }\end{array}$} & \multicolumn{2}{|c|}{$\begin{array}{c}\text { Natural } \\
\text { Science } \\
\text { Learning } \\
\text { Integrated the } \\
\text { Disaster } \\
\text { Mitigation }\end{array}$} \\
\hline Item & $\begin{array}{l}\text { Sig. (2- } \\
\text { tailed) }\end{array}$ & Item & $\begin{array}{l}\text { Sig. (2- } \\
\text { tailed) }\end{array}$ & Item & $\begin{array}{l}\text { Sig. (2- } \\
\text { tailed) }\end{array}$ \\
\hline$A 2$ & 0.004 & C27 & 0.000 & D37 & 0.001 \\
\hline A3 & 0.010 & C28 & 0.001 & D38 & 0.001 \\
\hline A4 & 0.019 & C29 & 0.000 & D39 & 0.011 \\
\hline A5 & 0.002 & C31 & 0.000 & D40 & 0.000 \\
\hline A6 & 0.000 & C32 & 0.000 & D41 & 0.018 \\
\hline A7 & 0.004 & C33 & 0.001 & D42 & 0.003 \\
\hline A8 & 0.001 & C34 & 0.002 & & \\
\hline A9 & 0.000 & C35 & 0.000 & & \\
\hline A10 & 0.015 & C36 & 0.044 & & \\
\hline A11 & 0.001 & & & & \\
\hline A12 & 0.000 & & & & \\
\hline
\end{tabular}

Table 2. Questionnaire relliability test

\begin{tabular}{|c|c|c|}
\hline $\begin{array}{c}\text { Subject } \\
\text { Specific } \\
\text { Pedagogy }\end{array}$ & $\begin{array}{c}\text { Disaster } \\
\text { Mitigation }\end{array}$ & $\begin{array}{c}\text { Natural Science } \\
\text { Learning } \\
\text { Integrated the } \\
\text { Disaster Mitigation }\end{array}$ \\
\hline \multicolumn{3}{|c|}{ Cronbach's alpha } \\
\hline 0.785 & 0.799 & 0.639 \\
\hline
\end{tabular}

Table 3. Criteria of achievement respondents level

\begin{tabular}{|c|c|c|}
\hline No. & Criteria & TCR Index (\%) \\
\hline 1 & Excellent & $90-100$ \\
\hline 2 & Good & $80-89$ \\
\hline 3 & Sufficient & $70-79$ \\
\hline 4 & Poor & $55-69$ \\
\hline 5 & Very poor & $1-54$ \\
\hline
\end{tabular}

\section{RESULT AND DISCUSSION}

Based on the analysis which has been performed, the percentage items questionnaire of three categories of questions:

\subsection{Teachers Perception about Subject Specific Pedagogy}

The first research question is teachers perception about Subject Specific Pedagogy. There are eleven items. The result of teachers reponse is provide on table 4.
Table 4. Response of respondents on subject specific pedagogy

\begin{tabular}{|c|c|c|c|c|}
\hline No. & Item & $\begin{array}{c}\text { Average } \\
\text { Score }\end{array}$ & $\begin{array}{c}\text { TRC } \\
\text { Index } \\
(\%)\end{array}$ & Criteria \\
\hline 1 & 2 & 4.42 & 88.46 & Good \\
\hline 2 & 3 & 3.92 & 78.46 & Sufficient \\
\hline 3 & 4 & 4.81 & 96.15 & Excellent \\
\hline 4 & 5 & 3.69 & 73.85 & Sufficient \\
\hline 5 & 6 & 4.65 & 93.08 & Excellent \\
\hline 6 & 7 & 4.77 & 95.38 & Excellent \\
\hline 7 & 8 & 3.19 & 63.85 & Poor \\
\hline 8 & 9 & 4.00 & 80.00 & Good \\
\hline 9 & 10 & 3.77 & 75.38 & Sufficient \\
\hline 10 & 11 & 3.15 & 63.08 & Poor \\
\hline 11 & 12 & 3.81 & 76.15 & Sufficient \\
\hline \multicolumn{2}{|c|}{$\begin{array}{c}\text { Average } \\
\text { Score }\end{array}$} & 4.02 & 80.35 & Good \\
\hline
\end{tabular}

Besides mastering the material, Natural Science teachers should have an ability in teaching, or which is known as PCK. According to [11], PCK is expressed as an interaction among PCK components, which are pedagogical and content knowledge that occur between teacher and students in teaching context.

PCK represents the combination of pedagogy and content in the understanding on how a certain topic or problem is managed and adjusted with interest and competence of students and is presented in instruction [12]. While SPP according to [13], is a packaging material of subject to become a set of educated and comprehensive learning. Therefore, it can be said that SSP has similar definition with PCK.

Based on Table 4, it is known that the average score of teachers' perception on SSP is 4.02 and TCR score is 80.35 and categorized as good. However, the score indicates minimum number of good category. Therefore, teachers' understanding on SSP should be sharpened. According to [14], one of causes of minimum teachers' SSP competence is learning patterns provided do not emphasize on pedagogical specific subject competence specifically. However, after joining peer-teaching and workshop, the competence of Pedagogical specific subject of teacher candidates have experienced sufficient increase. Besides joining workshop, they should be accustomed to performing SSP organization. Therefore, SSP development in Natural Science learning should be performed and make it as a guidance and is used by teachers in implementing the learning. It is expected that teachers' good knowledge on SSP will make them to have an ability to arrange SSP well. The results obtained, students should be 
able to follow the learning enthusiastically and the learning objective is achieved.

\subsection{Teachers Perception about Disaster Mitigation}

The second research question is teachers perception about disaster mitigation. There are nine items. The result is provide on table 5 .

Table 5. Teachers perception about disaster mitigation

\begin{tabular}{|c|c|c|c|c|}
\hline No. & Item & $\begin{array}{c}\text { Average } \\
\text { Score }\end{array}$ & $\begin{array}{c}\text { TRC } \\
\text { Index } \\
(\%)\end{array}$ & Criteria \\
\hline 1 & 27 & 3.88 & 77.69 & Sufficient \\
\hline 2 & 28 & 4.38 & 87.69 & Good \\
\hline 3 & 29 & 4.38 & 87.69 & Good \\
\hline 4 & 31 & 4.46 & 89.23 & Good \\
\hline 5 & 32 & 4.62 & 92.31 & Excellent \\
\hline 6 & 33 & 4.23 & 84.62 & Good \\
\hline 7 & 34 & 3.77 & 75.38 & Sufficient \\
\hline 8 & 35 & 3.42 & 68.46 & Poor \\
\hline 9 & 36 & 4.58 & 91.54 & Excellent \\
\hline \multicolumn{2}{|c|}{ Average } & 4.19 & 80.85 & Good \\
\hline \multicolumn{2}{|c|}{ Score } & & & \\
\hline
\end{tabular}

Based on table 5, there are nine items of the questionnaire. It is obtained the result of various respondents' achievement level criteria, which are poor, sufficient, good, and excellent. However, in average, good criteria result of teachers' perception on disaster mitigation has low score and is in category. The limit of good category is $80 \%$, while the average is $83.35 \%$.

However, teachers' ability towards disaster mitigation in learning should be improved. According to [15], concerning the capacity of teachers' professionalism in teaching, $87 \%$ teachers acknowledge that they have limited knowledge on disaster prevention. Therefore, teachers' training on disaster mitigation should be done. It is relevant with [16], considering that disaster is a sensitive issue which involves high uncertainty level, including the cause and effect of the disaster itself. So we need much effort to prepare and support teachers to handling disaster in the classroom. Therefore, the development of SSP Natural Science which is integrated with earthquake mitigation can become a reference in performing disaster learning.

\subsection{Teachers Perception about Natural Science Learning Integrated The Disaster Mitigation}

The last research question is teachers perception about natural science learning integrated the disaster mitigation. There are six items. The result is provide on table 6.

Table 6. Teachers perception about Natural Science Learning Integrated the disaster mitigation

\begin{tabular}{|c|c|c|c|c|}
\hline No. & Item & $\begin{array}{c}\text { Average } \\
\text { Score }\end{array}$ & $\begin{array}{c}\text { TRC } \\
\text { Index } \\
(\%)\end{array}$ & Criteria \\
\hline 1 & 37 & 3.23 & 64.62 & Poor \\
\hline 2 & 38 & 4.27 & 85.38 & Good \\
\hline 3 & 39 & 3.96 & 79.23 & Sufficient \\
\hline 4 & 40 & 2.77 & 55.38 & Poor \\
\hline 5 & 41 & 4.58 & 91.54 & Excellent \\
\hline 6 & 42 & 3.19 & 63.85 & Poor \\
\hline $\begin{array}{c}\text { Average } \\
\text { Score }\end{array}$ & 3.67 & 73.33 & Sufficient \\
\hline
\end{tabular}

Based on table 6, it is known that the average of teachers' achievement level on Natural Science learning which is integrated with disaster mitigation indicates score $73.33 \%$. Therefore, it is said that teachers' perception on Natural Science learning which is integrated with disaster mitigation is categorized as moderate. Certainly, the result need to be increased. According to [15], the lack of teachers' understanding is caused by their weakness in teaching natural disaster prevention. It occurs because the limited professional teachers' training frequency. Besides, many teachings of disaster prevention practice rely on textbook and pictures as the learning media seems ineffective. Therefore, development of Natural Science learning SSP which is integrated with disaster mitigation does not only rely on textbooks and pictures as the media but also relevant and interesting learning media and approach.

According to [16], the integration of Natural Science and disaster mitigation education will help breaking the limit between them in teaching it. Usually, disasters education in many countries is not part of the formal curriculum. Some lessons are arranged to integrate. Therefore, it will build students' holistic understanding on disaster which involves humanity, social, and students' scientific aspects. Thus, the development of Natural learning which is integrated with disaster mitigation in form of SSP should be done. So, disaster education can be taught holistically or as a whole in Natural Science, Social, or environmental aspects on causes and effects of the disaster. 


\section{CONCLUSION}

It is concluded that Natural Science teachers and teacher candidates' knowledge on SSP, disaster mitigation, and Natural Science learning which are integrated with disaster mitigation are included in good, good, and moderate category. This finding strengthens that Natural Science is a strategical learning material to introduce early disaster mitigation education.

\section{REFERENCES}

[1] V.O. Wati, S.R. Apresian, E.A.S. Dewi, The Collaboration between Indonesia and Pasific Island Countries in Facing Environmental Challenges, Jurnal Ilmiah Hubungan Internasional 14(1) (2018) 137-148. DOI: https://doi.org/10.26593/jihi.v14i1.2834.137$\underline{148}$

[2] Sutikno, Earthquake Disaster of Yogyakarta and Central Java, and Disaster Reduction, Indonesia, Forum Geografi 21(1) (2016) 1-16. DOI: https://doi.org/10.23917/forgeo.v21i1.1823

[3] A. Sabtaji, Statistik Kejadian Gempa Bumi Tektonik tiap Provinsi di Wilayah Indonesia Selama 11 Tahun Pengamatan (2009-2019), Buletin Meteorologi, Klimatologi, dan Geofisika 1(7) (2020) 31-46.

[4] D. Sarah, E. Soebowo, Liquefaction due to the 2006 Yogyakarta earthquake: field occurrence and geotechnical analysis, in: Procedia - Earth Planetary Science, vol. 6, Elsevier, Amsterdam, 2013, pp. 383-389. DOI: https://doi.org/10.1016/j.proeps.2013.01.050

[5] R. Pancasilawan, S.B. Utami, A. Sumaryana, S.U. Ismanto, D. Rosmalasari, Mitigation of Disaster Risk Reduction in Pangandaran Regency, Sosiohumaniora: Journal of Social Sciences and Humanities 22(2) (2020) 214-222. DOI:

https://doi.org/10.24198/sosiohumaniora.v22i2.2 5792

[6] R. B. Prihatin, Masyarakat Sadar Bencana: Pembelajaran dari Karo, Banjarnegara, dan Jepang, Aspirasi: Jurnal Masalah-masalah Sosial 9(2) 2018) 221-239. DOI: https://doi.org/10.46807/aspirasi.v7i1.1084

[7] J. Maknun, Pembelajaran Mitigasi Bencana Berorientasi Kearifan Lokal pada Pembelajaran IPA di Sekolah Menengah Kejuruan, ATIKAN:
Jurnal Kajian Pendidikan 5(2) (2015) 143-156. DOI: $\quad$ https://doi.org/10.2121/atikanjournal.v5i2.741

[8] M.M. Rahman, I.A. Nabila, F. Islam, F. Tasnim, S. Tabassum, K.N. Tanni, T. Roy, Challenges to Implement Disaster Risk Reduction in Schools of Developing Country: Study On Dhaka City, Bangladesh, International Journal of Sustainable Development Research 6(2) (2020) 37-42. DOI: https://doi.org/10.11648/j.ijsdr.20200602.13

[9] S. Handayani, I. Wilujeng, Pengembangan Subject Specific Pedagogy Berbasis Inkuiri untuk Meningkatkan Keterampilan Proses dan Motivasi Belajar IPA, Jurnal Pendidikan Matematika dan Sains 5(1) (2017) 22-35. DOI: https://doi.org/10.21831/jpms.v5i1.13537

[10] I. Wilujeng, Z.K. Prasetyo, Djukri, Development the subject specific pedagogy (SSP) of natural science to optimize mastery knowledge, attitude, and skills junior high school students in Yogyakarta, in: Proceeding of 3rd International Conference on Research, Implementation and Education of Mathematics and Science, Vol. 3, Universitas Negeri Yogyakarta, Yogyakarta, 2016, pp. 53-60.

[11] P. Nilsson, G. Karlsson, Capturing Student Teachers' Pedagogical Content Knowledge (PCK) Using Cores and Digital Technology, International Journal Science Education 41(4) (2019) 419-447. DOI: https://doi.org/10.1080/09500693.2018.1551642

[12] L.S. Shulman, Knowledge and Teaching: Foundations of The New Reform. Harvard Educational Review, 1987.

[13] A. Acesta, Development of subject specific pedagogy in integrated science learning in elementary school, in: Journal of Physics: Conference Series, vol. 1318, IOP Publishing, Bristol, 2019, pp.1-6. DOI: https://doi.org/10.1088/17426596/1318/1/012112

[14] Y. Anwar, N.Y. Rustaman, A. Widodo, Kemampuan Subject Specific Pedagogy Calon Guru Biologi Peserta Program Pendidikan Profesional Guru (PPG) yang Berlatar Belakang Basic Sains Pra dan Post Workshop, Jurnal Pendidikan IPA Indonesia 1(2) (2012) 157-162. DOI: https://doi.org/10.15294/jpii.v1i2.2133 
[15] Tuswadi, T. Hayashi, Disaster prevention education in Merapi Volcano area primary schools: focusing on students' perception and teachers' performance, in: Procedia Environment Science, vol. 20, Elsevier, Amsterdam, 2014, pp. 668-677. DOI: https://doi.org/10.1016/j.proenv.2014.03.080

[16] W. Park, Beyond The 'Two Cultures' in The Teaching of Disaster: Or How Disaster Education and Science Education Could Benefit Each Other, Education Philosophy Theory 52(13) (2020) 1434-1448. DOI: https://doi.org/10.1080/00131857.2020.1751126 